PERM JOURNAL OF PETROLEUM AND MINING ENGINEERING ВЕСТНИК ПНИПУ. ГЕОЛОГИЯ. НЕФТЕГАЗОВОЕ И ГОРНОЕ ДЕЛО ISSN 2224-9923 Volume/Tom 19 №1 2019

http://vestnik.pstu.ru/geol

UDC 622.276+622.361.1:544.638

Article / Статья

(C) PNRPU / ПНИПУ, 2019

\title{
ZETA POTENTIAL CHANGING IN COMPRESSED CLAYS
}

\section{Natalia A. Medvedeva, Karine A. Alvanyan, Yulia O. Malgina, Valery V. Seredin}

Perm State National Research University (15, Bukireva st., Perm, 614068, Russian Federation)

\section{ИЗМЕНЕНИЕ ДЗЕТА-ПОТЕНЦИАЛА ГЛИН, ПОДВЕРЖЕННЫХ СЖАТИЮ}

\section{Н.А. Медведева, К.А. Алванян, Ю.О. Мальгина, В.В. Середин}

Пермский государственный национальный исследовательский университет (614068, Россия, г. Пермь, ул. Букирева, 15)

Received / Получена: 10.07.2018. Accepted / Принята: 14.01.2019. Published / Опубликована: 29.03.2019

Key words:

clay, montmorillonite, kaolinite, clay particles, zeta potential, EDL, pressure, colloid, mineral, suspension, structural bonds, particle size analysis, fraction, correlation analysis, engineering geology.

\begin{abstract}
Experimental results concerning the effect of loading pressure on the electrokinetic potential of kaolinite and montmorillonite particles in aqueous suspension are presented. It has been determined that the investigated suspensions of kaolinite and montmorillonite are aggregatively and sedimentally stable. The aggregative stability is evidenced by the calculated energy of the molecular motion $\left(10^{-7}-10^{-8} \mathrm{~J} / \mathrm{m}^{2}\right)$. The monitoring of particle size indicates sedimentation stability. It was found that the change in the electrokinetic potential of clay particles depends on the loading pressure in different ways. Three classes were distinguished: 0-125 MPa, 150-750 MPa, 800-1200 MPa. In each class, characteristic changes in the electrokinetic potential are observed, due to the nature of the clay and the fractional composition. The fractional composition of the clay is also changed while compression. Pressure load has a different effect on the change in electrokinetic potential for kaolinite and montmorillonite. To establish the influence of the particle size distribution on the conditions of formation of the zeta potential on the surface of clay particles, a statistical correlation analysis was performed. It was established that for montmorillonite in the 1st and 2nd classes, the particle size distribution and zetapotential have statistical correlations, and in 3rd class - not, whereas for kaolinite, statistical correlations between the particle size distribution and zeta potential are observed in the 1 st and 3rd classes, and in the 2 nd class - not. The resulting changes in the zeta potential are associated with the processes of dispersion and aggregation, which are implemented more intensively at low pressures $(p<150 \mathrm{MPa})$.
\end{abstract}

Представлены экспериментальные результаты, касающиеся влияния нагружаемого давления на электрокинетический потенциал частиц каолинита и монтмориллонита, находящихся в водной суспензии. Определено, что исследуемые суспензии каолинита и монтмориллонита агрегативно и седиментационно устойчивые. Об агрегативной устойчивости

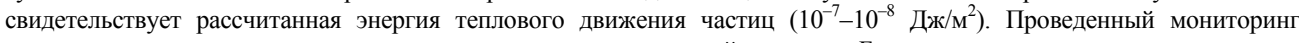
размеров частиц указывает на седиментационную устойчивость. Было установлено, что изменение электрокинетического потенциала глинистых частиц в зависимости от нагружаемого давления происходит поразному. Было выделено три класса: 0-125 МПа, 150-750 МПа, 800-1200 МПа. В каждом классе наблюдаются характерные изменения электрокинетического потенциала, обусловленные природой глины и фракционным составом. Фракционный состав также подвержен изменению в ходе сжатия глин. Нагрузка давлением по-разному оказывает влияние на изменение электрокинетического потенциала для каолинита и монтмориллонита. Для установления влияния гранулометрического состава на условия формирования дзета-потенциала на поверхности глинистых частиц был проведен статистический корреляционный анализ. Установлено, что для монтмориллонита в 1-м и 2-м классах гранулометрический состав и дзета-потенциал имеют статистические связи, а в классе 3 - нет, тогда как для каолинита между гранулометрическим составом и дзета-потенциалом наблюдаются статистические связи в 1-м и 3-м классах, а во 2-м связь отсутствует. Полученные изменения дзета-потенциала связаны с процессами диспергации и агрегации, которые реализуются интенсивнее при невысоких давлениях ( $p<150 \mathrm{MПа).}$

Natalia A. Medvedeva (Author ID in Scopus: 55164437300) - PhD in Chemistry, Associate Professor at the Department of Physical Chemistry (tel.: +00790247843 11, e-mai: nata-kladova@yandex.ru).

Karine A. Alvanyan - Senior Lecturer at the Department of Engineering Geology (tel.: +007 34223964 39, e-mail: karishuta@yandex.ru).

Yulia O. Malgina - Master's student at the Department of Engineering Geology (tel.: +007 34223964 39, e-mail: karishuta@yandex.ru).

Valery V. Seredin (Author ID in Scopus: 56974744000 ) - Doctor of Geology and Mineralogy, Professor, Head of the Department of Engineering Geology (tel.: +007 3422396439, e-mail: seredin@nedra.perm.ru). The contact person for correspondence.

Медведева Наталья Александровна - кандидат химических наук, доцент кафедры физической химии (тел.: +007902 478 4311 , e-mai: nata-kladova@yandex.ru) Алванян Карине Антоновна - старший преподаватель кафедры инженерной геологии (тел.: +007 342 239 64 39, e-mail: karishuta@yandex.ru). Мальгина Юлия Олеговна - магистр кафедры инженерной геологии (тел.: +007 34223964 39, e-mail: karishuta@yandex.ru).

Середин Валерий Викторович - профессор, доктор геолого-минералогических наук, заведующий кафедрой инженерной геологии (тел.: +007 3422396439 , e-mail: seredin@nedra.perm.ru). Контактное лицо для переписки. 


\section{Introduction}

The clays properties are largely determined by the energy potential formed on the clay particles surface $[1,2]$. One of the components of the energy potential is the electrokinetic potential (zeta potential), which is formed at the sliding boundary between the adsorption and diffusion layers [3]. Zeta potential is determined both by the charge of the particle itself and by external environmental conditions. There are several factors that determine the electrical charge on the clay particles surface: defects in the crystal lattice [4-13], $\mathrm{pH}$ of the solution, type and concentration of cations in pore solution, effect of indifferent electrolytes [9, 14, 15], effect of non-indifferent electrolytes, effect of temperature $[15,16]$, influence of the dispersion medium nature [15-17]. The magnitude of the particle charge significantly affects on formation of strength [18] and adsorption properties of clays [19-22], as well as transformation of fluid in the soil mass [23]. So, in the article V.I. Osipova [24] process of water molecules adsorption by silicate surfaces of clay minerals, leading to the formation of nanoscale films of adsorbed water is described.

Much attention is paid to the study of the electric charge of dispersed soils particles and the laws of its formation [4-6, 25-27]. The factor that determines the clays adsorption activity and, as a consequence, the particles charge, is the loading pressure. As a result of high pressure and pressure with a shift in certain areas of a solid, a stress field is created, the relaxation of which occurs in different ways: heat generation, formation of new surfaces and short-lived active centers, formation of plastic waves, the interaction of which leads to the formation of various types of defects in the structure and metastable states [28-31]. Experimental study of kaolinite, halloysite, montmorillonite, sepiolite, palygorskite and illite structures behavior under the influence of different types of pressure made it possible to establish that the degree of structures perfection and the interpacket material distribution depend both on the interlayer bonds nature and the type of pressure [32].

The effect of pressure (technogenic load) on the zeta potential of clay minerals is rather poorly studied; therefore the purpose of this study is to establish the pattern of zeta potential changing in clays prone to shear compression.

The objects of study are Lobanov's montmorillonite and Chelyabinsk's kaolinite. According to the results of X-ray analysis [33], montmorillonite clay consists of: montmorillonite $(75 \%)$; kaolinite $(3.6 \%)$, quartz $(11.4 \%)$, albite $(6.7 \%)$, calcite $(3.3 \%)$. Kaolinite clay contains: kaolinite $(76.7 \%)$, montmorillonite (15.6\%), quartz (7.7\%).

The clay was subjected to compression, which was produced on a specially designed and manufactured device according to the method described in [34]. Before experiments, clays were cleaned by sedimentation method of $2 \%$ aqueous clay suspensions. For pressing, clay samples with fractions greater than $0.01 \mathrm{~mm}$ were used.

In research suspensions content $0.5 \%$ of clay.

\section{Patterns of changes in zeta potential in clays subjected to mechanical pressure treatment}

Determination of the clays electrokinetic characteristics (electrokinetic potential) in water, as well as structural parameters (particle size) was carried out using an automated system of electrokinetic properties studying of colloidal systems and surfaces DelsaNanoC of Beckman Coulter (USA). The particle size was measured in a cell with a quartz cuvette, and the zeta potential of clay particles was measured in a flow cell. Measurements of particle size and electrokinetic characteristics are based on photon correlation spectroscopy (PCS), which use principle of dynamic light scattering and electrophoretic light scattering [35]. 
Simultaneously with the measurement of particle size and zeta potential of clay suspensions, the structural parameters were monitored over time. The criterion for these measurements was the accumulation time that characterizes the accumulation of data and is expressed in arbitrary units [1]. The determination of polydispersity (P.I.) was carried out on the basis of the intensity distribution depending on the particle size.

One of the important factors in the electrokinetic characteristics measurement is the stability of the systems. In this case, we are talking about both aggregative and sedimentation stability. The attainment of sedimentation stability of the clay suspensions was confirmed by the results of over time particle size monitoring (Fig. 1).

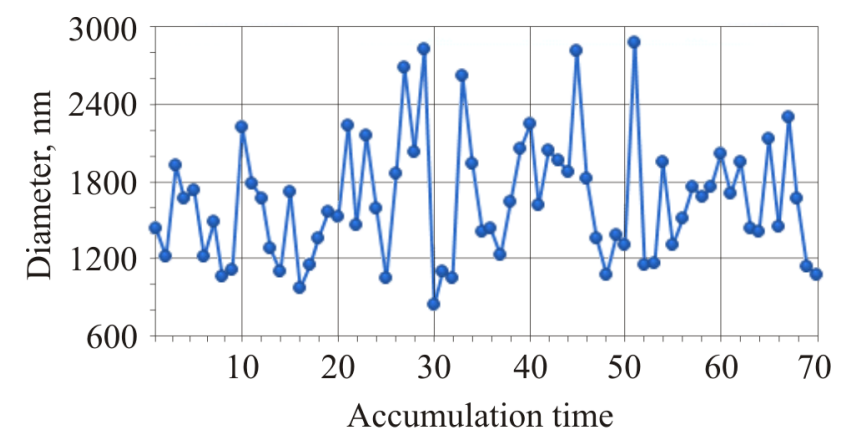

Fig. 1. Monitoring the size of montmorillonite clay particles in water

In order to assess the aggregative stability of particles of clay minerals, the energy of thermal motion of particles was calculated

$$
\sigma_{m}=\gamma \frac{k T}{d^{2}}
$$

where $\gamma \sim 10$ - dimensionless coefficient; $k$ - the Boltzmann constant $\left(1,38 \cdot 10^{-23} \mathrm{~J} / \mathrm{K}\right)$; $T$ - temperature, $\mathrm{K} ; d$ - the size of the structural unit, $\mathrm{m}$ [37].

This characteristic is used as a criterion for aggregative stability, to calculate which the average diameter of clay particles in the aqueous suspension was determined. For some pressures, the results are shown in Table 1.
Table 1

Change in average diameter, polydispersity and thermal movement energy of clay particles depending on the loaded pressure

\begin{tabular}{|l|c|c|c|c|c|c|}
\hline \multirow{2}{*}{$\begin{array}{c}P, \\
\mathrm{MPa}\end{array}$} & \multicolumn{3}{|c|}{ Kaolinite } & \multicolumn{3}{c|}{ Montmorillonite } \\
\cline { 2 - 7 } & $d_{a v} \cdot 109, \mathrm{~m}$ & P.I. & $\begin{array}{c}\sigma_{m} \cdot 108, \\
\mathrm{~J} / \mathrm{m}^{2}\end{array}$ & $d_{a v} \cdot 109, \mathrm{~m}$ & P.I. & $\begin{array}{c}\sigma_{m} \cdot 108, \\
\mathrm{~J} / \mathrm{m}^{2}\end{array}$ \\
\hline 0 & $720 \pm 15$ & 0.30 & 7.93 & $800 \pm 59$ & 0.34 & 6.43 \\
\hline 60 & $883 \pm 85$ & 0.36 & 5.26 & $680 \pm 40$ & 0.28 & 8.88 \\
\hline 105 & $776 \pm 90$ & 0.32 & 6.81 & $877 \pm 23$ & 0.24 & 5.34 \\
\hline 200 & $592 \pm 63$ & 0.30 & 11.71 & $1023 \pm 85$ & 0.35 & 3.92 \\
\hline 550 & $1450 \pm 100$ & 0.34 & 1.96 & $714 \pm 47$ & 0.20 & 8.06 \\
\hline
\end{tabular}

It should be noted that, along with nanoscale particles, the presence of their agglomerates, as well as micron-range grains, is characteristic of dispersed systems. These large particles cannot be determined, since they do not possess sedimentation stability (they quickly settle) and are not suspended in the measurement process $[36,37]$. The calculated values of $\sigma \mathrm{m}$ are in the range from $10-7$ to $10-8 \mathrm{~J} / \mathrm{m}^{2}$, which indicate the aggregative stability of the system, but the kinetically - studied systems are weakly stable.

The homogeneity of the system is indicated by the polydispersity index, whose values do not exceed 0.4.

After carrying out a series of tests, graphs of changes in the zeta-potential of kaolinite and montmorillonite clay particles were plotted depending on the loading pressure (Fig. 2).

Figure 2, a shows the dependence of the zeta potential of montmorillonite clay from pressure. From the graph it can be seen that at a pressure from 0 to $125 \mathrm{MPa}$, the zeta potential decreases in absolute value from -36 to $-16 \mathrm{mV}$. At a pressure from 150 to $750 \mathrm{MPa}$, the zeta potential increases in the absolute value from -18 to $-38 \mathrm{mV}$, and at pressure from 800 to $1200 \mathrm{MPa}$, the zeta potential varies chaotically from -30 to $-40 \mathrm{mV}$. Figure $2, b$ shows the dependence of the zeta potential of 
kaolin clay from the pressure; three areas can be distinguished in the graph: the first, at pressures from 0 to $125 \mathrm{MPa}$, the zeta potential varies from -55 to $-45 \mathrm{mV}$, the second, from 150 to $750 \mathrm{MPa}$, where zeta potential increases from -52 to $-30 \mathrm{mV}$. The third is in the pressure range from 800 to $1200 \mathrm{MPa}$, in which the zeta potential varies chaotically.

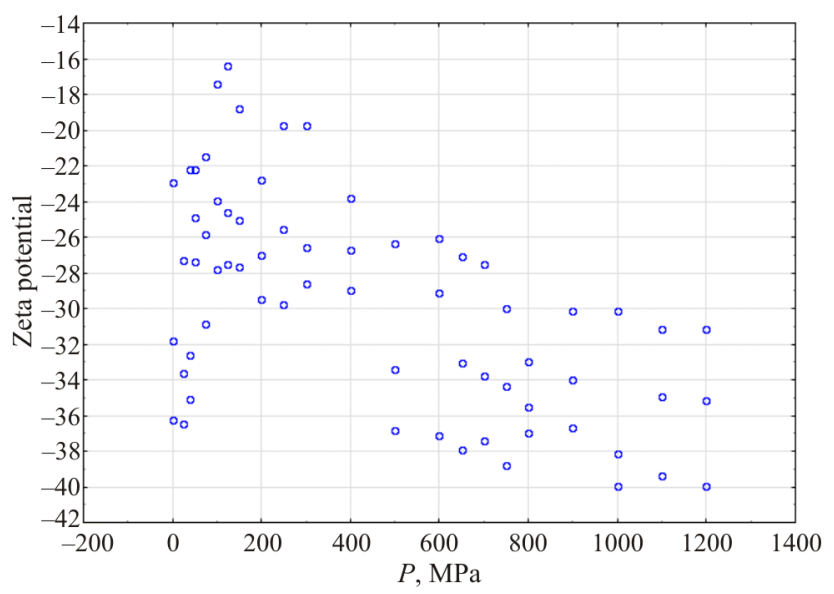

$a$

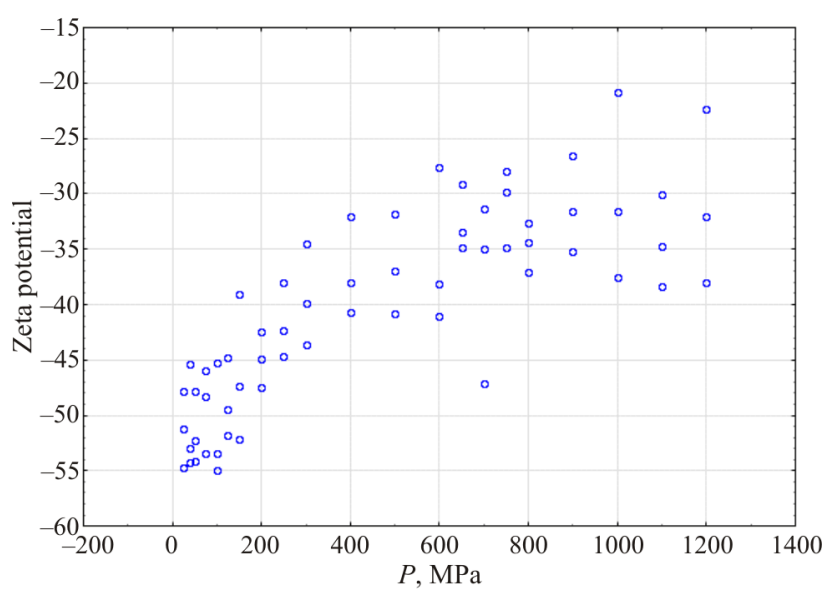

$b$

Fig. 2. Changes in the zeta potential $(\zeta)$ of clay particles subjected to pressure $(\mathrm{P})$ : $a$ - scatter diagram of the zeta potential as a function of pressure for Lobanov's montmorillonite; $b-$ scatter diagram of the zeta potential as a function of pressure for kaolinite

Thus, three classes in this pressure range can be preliminarily distinguished for each clay: 1st class - 0-125 $\mathrm{MPa}$, 2nd class 150-750 MPa, 3rd class - 800-1200 MPa.
It can be seen that the load affects kaolinite and montmorillonite differently. This circumstance may be due to several reasons. First, isomorphic substitutions in the crystal lattice of clay minerals: for example, for clay minerals of type 2: 1 (minerals that consist of two tetrahedral and one octahedral sheet, which include montmorillonite), substitutions of $\mathrm{Si}^{4+}$ by $\mathrm{Al}^{3+}$ in the tetrahedral sheet and substitutions of $\mathrm{Al}^{3+}$ by $\mathrm{Mg}^{2+}$ and $\mathrm{Fe}^{2+}$ in the octahedral sheet $[6,9]$. It is believed that isomorphic substitutions are not characteristic of kaolinite [6], however, a number of authors note that isomorphic substitutions of $\mathrm{Al}^{3+}$ by $\mathrm{Si}^{4+}$ occur in tetrahedral sheets in kaolinite [7, 10]. Isomorphic substitutions are known to affect the charge of clay minerals basal surfaces (siloxane and hydroxyl) [12]. The structural sheet of kaolinite has a siloxane and hydroxyl surfaces, while the structural sheet of montmorillonite has only siloxane surfaces.

Secondly, the formation of a constant structural charge is also due to the electronegativity of the chemical elements atoms that the clay mineral is consisted of [38-41].

Third, the fractional composition. An increase in the content of the fine fraction due to the clays mechanical activation leads to an increase in the zeta potential absolute value $[29,30]$. In addition, it is necessary to take into account the electric charge localization heterogeneity in different parts of the particles of a clay mineral.

Thus, the classes allocated for Lobanov's montmorillonite according to the graph of dependence of $\mathrm{R}$ on $\mathrm{P}$ are the following: 1st class - 0-125 $\mathrm{MPa}, 2$ nd class 150-600 MPa, 3rd class - 650-1200 MPa. For the Chelyabinsk kaolinite according to the dependence of $\mathrm{R}$ on $\mathrm{P}$, the following: 1st class 0-125 MPa, 2nd class - 150-400 MPa, 3rd class - 500-1200 MPa. 


\section{The influence of particle size distribution on the zeta-potential formation conditions on the clay particles surface}

To study the effect of the particle size distribution on the zeta potential value change 3 , graphs of the change in the zeta potential of clays were plotted depending on the percentage of fractions with a particle size: less than $0.1 ; \quad 0.1-0.2 ; \quad 0.2-0.5 ; \quad 0.5-1.0 ; \quad 1-2 ; \quad 2-5$; 5-50 microns. The method of the granulometric composition determining of the clays under pressure, as well as the rationale of the effect of pressure on the formation of the granulometric composition of the clays, were previously studied and described in [33, 34]. Experimentally it was found that with increasing pressure on the clay, there is a general tendency of the clay fractions content decreasing and the silt fraction increasing. Such changes occur more intensively in kaolinite clay than in argillite-like montmorillonite. It was revealed that in the pressure range of $0-125 \mathrm{MPa}$, the change in the clays fractional composition proceeds more intensively than at higher pressures.

Based on the obtained results of particle size analysis, a statistical analysis was carried out and the correlation coefficient for each fraction by classes was derived. The results for montmorillonite and kaolinite are presented in Tables 2 and 3 respectively.

Table 2

Values of correlation coefficients between the zeta potential and granulometric composition of montmorillonite clay

\begin{tabular}{|l|c|c|c|c|c|c|}
\hline \multirow{2}{*}{ Fraction } & \multicolumn{2}{|c|}{ Class 1 } & \multicolumn{2}{c|}{ Class } & \multicolumn{2}{c|}{ Class3 } \\
\cline { 2 - 7 } & $r(n=21)$ & $r_{\mathrm{T}}(n=21)$ & $r(n=30)$ & $r_{\mathrm{r}}(n=30)$ & $r(n=15)$ & $r_{\mathrm{T}}(n=15)$ \\
\hline $\begin{array}{l}\text { Less } \\
\text { than } 0.1\end{array}$ & $-0,52$ & -0.43 & -0.36 & -0.36 & 0.13 & 0.51 \\
\hline $0.1-0.2$ & -0.50 & -0.43 & 0.46 & 0.36 & -0 & -0.51 \\
\hline $0.2-0.5$ & -0.59 & -0.43 & 0.70 & 0.36 & -0.42 & -0.51 \\
\hline $0.5-1.0$ & -0.66 & -0.43 & 0.66 & 0.36 & -0.34 & -0.51 \\
\hline $1-2$ & -0.48 & -0.43 & 0.69 & 0.36 & -0.51 & -0.51 \\
\hline $2-5$ & -0.54 & -0.43 & 0.67 & 0.36 & -0.30 & -0.51 \\
\hline $5-50$ & 0.69 & 0.43 & -0.60 & -0.36 & 0.33 & 0.51 \\
\hline
\end{tabular}

N o te : here and in Table 3 red indicates insignificant correlation coefficients.
Table 2 shows that for montmorillonite in classes 1 and 2, size distribution and zeta potential have a statistical correlation, since the calculated correlation coefficients are larger than table values. In class 3 , the correlation is weak, due to the lack of influence of particle size distribution on the formation of the electrokinetic potential.

It should be noted that in class $1(0-125 \mathrm{MPa})$, the zeta potential decreases with an increase in the percentage of the clay fraction (less than 0.1-5.0 $\mu \mathrm{m})$, whereas with an increase in the content of the silt fraction $(5-50 \mu \mathrm{m})$, the potential increases. In class $2(150-750 \mathrm{MPa})$, an increase in the zeta potential is observed with an increase in the percentage of fractions $0.1-5.0 \mu \mathrm{m}$. And with an increase of content of the fraction less than 0.1 and 5-50 $\mu \mathrm{m}$, the zeta potential value decreases. It is assumed that an increase in the content of the clay fraction particles, which remain in suspension, leads to an increase in zeta potential.

Table 3

Values of correlation coefficients

between the zeta potential and granulometric composition of kaolinite clay

\begin{tabular}{|l|c|c|c|c|c|c|}
\hline \multirow{2}{*}{ Fraction } & \multicolumn{2}{|c|}{ Class 1 } & \multicolumn{2}{c|}{ Class 2 } & \multicolumn{2}{c|}{ Class 3 } \\
\cline { 2 - 7 } & $r(n=18)$ & $r_{\mathrm{r}}(n=18)$ & $r(n=30)$ & $r_{\mathrm{T}}(n=30)$ & $r(n=15)$ & $r_{\mathrm{r}}(n=15)$ \\
\hline $\begin{array}{l}\text { Less } \\
\text { than } 0.1\end{array}$ & -0.16 & -0.47 & 0.58 & 0.36 & 0.18 & 0.51 \\
\hline $0.1-0.2$ & -0.20 & -0.47 & -0.15 & -0.36 & 0.26 & 0.51 \\
\hline $0.2-0.5$ & -0.21 & -0.47 & -0.66 & -0.36 & 0.34 & 0.51 \\
\hline $0.5-1.0$ & -0.24 & -0.47 & -0.64 & -0.36 & 0.33 & 0.51 \\
\hline $1-2$ & -0.22 & -0.47 & -0.72 & -0.36 & 0.28 & 0.51 \\
\hline $2-5$ & -0.10 & -0.47 & -0.75 & -0.36 & -0.16 & -0.51 \\
\hline $5-50$ & 0.20 & 0.47 & 0.61 & 0.36 & 0.25 & 0.51 \\
\hline
\end{tabular}

In class 3 (800-1200 MPa), with an increase in the percentage of fractions $0.1-5.0 \mu \mathrm{m}$, the zeta potential decreases. With an increase in the percentage of fractions less than 0.1 and $5-50 \mu \mathrm{m}$, the value of the zeta potential increases.

Table 3 presents the results of statistical analysis for kaolinite, it is shown that in classes 1 and 3, the particle size distribution and the zeta potential do not have statistical relationships. 
In class 2, excepted the fraction $0.1-0.2$, statistical relationships are observed between the particle size distribution and the zeta potential.

Thus, the described changes in the zeta potential can be associated with the processes of dispersion and aggregation, which are implemented more intensively at low pressures $(P<150 \mathrm{MPa})$. It is assumed that the particles of the silt fraction precipitate, and the content of sedimentation-resistant particles of the clay fraction, which remain suspended, decreases, which leads to a drop in the zeta potential.

\section{Conclusion}

Physico-chemical properties of soils are largely determined by the size of their structural elements. The magnitude of the electrokinetic potential is a criterion, the use of which will make it possible to predict the structural changes of clay minerals in various environments.

With increasing pressure on clay, the electrokinetic potential of the particles changes in different directions. Zeta-potential formation is associated with both the size of the particles and their mineral composition.

\section{References}

1. Seredin V.V., Krasilnikov P.A., Medvedeva N.A. Izmenenie elektrokineticheskogo potentsiala glinistykh kolloidov $\mathrm{v}$ vodnoy $\mathrm{i}$ uglevodorodnoy sredakh [Variation of electrokinetic potential of clayey colloids in aquatic and hydrocarbon media]. Geoekologiya, inzhenernaya geologiya, gidrogeologiya, geokriologiya, 2017, no.1, pp.66-74.

2. Buckley J.S., Takamura K., Morrow N.R. Influence of electrical surface charges on the wetting properties of crude oils. SPE Reservoir Engineering, 1989, vol.4, iss.03, pp.332-340. DOI: 10.2118/16964-PA

3. Yukselen Y., Kaya A. Zeta potential of kaolinite in the presence of alkali, alkaline earth and hydrolyzable metal ions. Water, Air, and Soil Pollution, 2003, vol.145, no.1-4, pp.155-168. DOI: 10.1023/A:1023684213383

4. Seredin V.V., Parshina T.U., Isaeva G.A. To the problem of the clay particles energy potential assessment. Bulletin of Perm University. Geology, 2017, vol.16, no.4, pp.370-381. DOI: 10.17072/psu.geol.16.4.370

5.Zlochevskaia R.I., Korolev V.A. Elektropoverkhnostnye iavleniia $\mathrm{v}$ glinistykh porodakh [Electro-surface phenomena in clay rocks]. Moscow, Izdatelstvo Moskovskogo gosudarstvennogo universiteta, 1988, $177 \mathrm{p}$.

6. Korolev V.A., Nesterov D.S. Fizikokhimicheskie zakonomernosti izmeneniya elektricheskikh zaryadov chastits glinistykh gruntov [Physico-chemical regularities of changes of the clay soil particles electrical charge]. Inzhenernaya geologiya, 2017, no.4, pp.50-60. DOI: 10.25296/1993-5056-2017-4-50-60

7. Tarasevich Yu.I., Ovcharenko F.D. Adsorbtsiya na glinistykh mineralakh [Adsorption on clay minerals]. Kiev, Naukova dumka, 1975, $352 \mathrm{p}$.

8. Van Olphen H., Fripiat J.J. Data handbook for clay minerals and other nonmetallic menirals. Oxford: Pergamon Press, 1979, $346 \mathrm{p}$.

9. Sokolova T.A., Trofimov S.Ya. Sorbtsionnye svoystva pochv. Adsorbtsiya. Kationnyy obmen [Sorption properties of soils. Adsorption. Cation exchange]. Tula, Grif i K, 2009, 172 p.

10. Moris P. Poverkhnost i mezhfaznye granitsy $\mathrm{V}$ okruzhayushchey srede. ot nanourovnya $\mathrm{k}$ globalnomu masshtabu [Environmental surfaces and interfaces from the nanoscale to the global scale]. Moscow, Binom. Laboratoriya znaniy, 2013, 543 p.

11. Kumar N., Cunlu Zhao, Aram Klaassen, Dirkvan den Ende, Frieder Mugele, Igor Siretanu. Characterization of the surface charge distribution on kaolinite particles using high resolution atomic force microscopy. Geochimica et cosmochimica acta, 2016, vol.175, pp.100-112. DOI: 10.1016/j.gca.2015.12.003 
12. Schoonheydt R.A., Johnston C.T. Surface and interface chemistry of clay minerals. Developments in clay science, 2006, vol.1, pp.87-113. DOI: 10.1016/S1572-4352(05)01003-2

13. Gupta V., Miller J. D. Surface force measurements at the basal planes of ordered kaolinite particles. J. Colloid Interface. Sci., 2010, vol. 344, iss. 2, pp.362-371. DOI: $10.1016 /$ j.jcis.2010.01.012

14. Voyutskiy S.S. Kurs kolloidnoy khimii [Course of colloid chemistry]. Moscow, Khimiya, 1976, 512 p.

15. Osipov V.I., Sokolov V.N., Rumyantseva N.A. Mikrostruktura glinistykh porod [The microstructure of clay rocks]. Ed. E.M. Sergeev. Moscow, Nedra, 1989, 211p.

16. Sokolov V.N. Glinistye porody i ikh svoystva [Clay rocks and their properties]. Nauki o zemle, 2000, vol.6, iss. 9, pp.59-65.

17. Stromberg A.G., Semchenko D.P. Fizicheskaya khimiya [Physical chemistry]. Moscow, Vysshaya shkola, 2001, 527p.

18. Seredin V.V., Andrianov A.V. $\mathrm{K}$ voprosu o metodike opredeleniya prochnostnykh kharakteristik gruntov [On the question about the method of getting strength characteristics of subsoils]. Sovremennye problemy nauki $i$ obrazovaniya, 2013, no.6, pp.946.

19. Goldovskaya-Peristaya L.F. et al. Izoterma sorbtsii ionov strontsiya montmorillonit-gidroslyudistymi glinami [Isotherm of sorption of strontium ions by montmorillonite-hydromicas clays]. Sorbtsionnye $i$ khromatograficheskie protsessy, 2011, vol.11, no.2, pp.165-171.

\section{Putilina V.S., Galitskaya I.V.,} Yuganova T.I. Sorbtsionnye protsessy pri zagryaznenii podzemnykh vod tyazhelymi metallami i radioaktivnymi elementami. Med [Sorption processes in the contamination of groundwater with heavy metals and radioactive elements. Copper]. Ekologiya. Seriya analiticheskikh obzorov mirovoy literatury, 2013, no.100, pp.3-93.
21. Mikhaylov N.N., Sechina L.S., Motorova K.A. Rol glinistykh mineralov $\mathrm{V}$ obrazovanii adsorbtsionno-svyazannoy nefti $\mathrm{v}$ porodakhkollektorakh uglevodorodnogo syrya [Role of clay minerals in formation of the adsorptionconnected oil in rock-collectors of hydrocarbonic raw materials]. Georesursy, geoenergetika, geopolitika, 2012, no.1(5), pp.51.

22. Ivanova E.S. Vozmozhnosti prognozirovaniya sorbtsionnoy aktivnosti prirodnoy gliny [Prognosis possibilities of natural clay sorption activity]. Izvestiya RGPU im. A.I. Gertsena. Khimiya, 2013, no.157, pp.90-95.

23. Krasilnikov P.A., Seredin V.V., Leonovich M.F. Issledovanie raspredeleniya uglevodorodov po razrezu gruntovogo massiva [Investigation of the distribution of hydrocarbons to cut the soil mass]. Fundamentalnye issledovaniya, 2015, no.2-14, pp.3100-3104.

24. Osipov V.I. Nanoplenki adsorbirovannoy vody $\mathrm{v}$ glinakh, mekhanizm ikh obrazovaniya $\mathrm{i}$ svoystva [Nanofilms of adsorbed water in clay: mechanism of formation and properties]. Geoekologiya, inzhenernaya geologiya, gidrogeologiya, geokriologiya, 2011, no.4, pp.291-305.

25. Korolev V.A. Teoriya elektropoverkhnostnykh yavleniy $\mathrm{v}$ gruntakh i ikh primenenie [Theory of electro-surface phenomena in soils and their application]. Moscow, Sam poligrafist, 2015, 468 p.

26. Nesterov D.S., Korolev V.A. $\mathrm{O}$ vliyanii $\mathrm{pH}$ sredy na elektricheskiy zariad chastits glinistykh gruntov [On the effect of the $\mathrm{pH}$ of the medium on the electrical charge of clay soil particles]. Geologiya $v$ razvivayushchemsya mire. Sbornik nauchnykh trudov. Materialy IX mezhdunarodnoy nauchnoprakticheskoy konferentsii studentov, aspirantov $i$ molodykh uchenykh. Perm, Permskiy gosudarstvennyy natsionalnyi issledovatelskii universitet, 2016, vol.1, pp.451-454.

27. Lin-Guan-tsan, Fridrikhsberg D.A. Issledovanie elektrokineticheskogo potentsiala $\mathrm{V}$ 
zavisimosti ot temperatury i drugikh faktorov [The study of electrokinetic potential depending on temperature and other factors]. Vestnik Leningradskogo gosudarstvennogo universiteta, 1963, no.16, iss.3, p.88.

28. Avakumov E.G., Boldyrev V.V. Fundamentalnye osnovy mekhanicheskoy aktivatsii, mekhanosinteza i mekhanokhimicheskikh tekhnologiy [Fundamental principles of mechanical activation, mechanosynthesis and mechanochemical technologies]. Novosibirsk, Izdatelstvo SO RAN, 2009, 343 p.

29. Iurev P.O., Kostin I.V., Rasskazova E.V., Tserna V.V. Issledovanie izmeneniia eletrostaticheskikh kharakteristik glin Taganskogo mestorozhdeniia ot stepeni mekhanoaktivivatsii [Investigation of changes in the electrostatic characteristics of clays of the Tagansky deposit on the degree of mechanical activation]. Molodezh $i$ nauka. Sbornik materialov $X$ iubileinoi vserossiiskoi nauchno-tekhnicheskoi konferentsii studentov, aspirantov $i$ molodykh uchenykh $s$ mezhdunarodnym uchastiem, posvyashchennoy 80-letiyu obrazovaniya Krasnoyarskogo kraya. Krasnoyarsk, Sibirskiy federalnyy universitet, 2014, available at: http:/conf.sfu-kras.ru/sites/ mn2014/directions.html (accessed 6 June 2018).

30. Suttiponparnit K., Jiang J., Sahu M., Suvachittanont S., Charinpanitkul T., Biswas P. Role of surface area, primary particle size, and crystal phase on titanium dioxide nanoparticle dispersion properties Nanoscale Res Lett, 2011, vol.6, no.1, p.27. DOI: $10.1007 / \mathrm{s} 11671-010-9772-1$

31. Frank-Kamenetskii V.A., Kotov N.V., Goilo E.A. Transformatsionnye preobrazovaniia sloistykh silikatov pri povyshennykh p-T parametrakh [Transformations of layered silicates at high $\mathrm{p}-\mathrm{T}$ parameters]. Leningrad, Nedra, 1983, $151 \mathrm{p}$.

32. Goylo E.A. Kristallokhimiya transformatsiy sloistykh silikatov [Crystal chemistry of transformation of layered silicates]. Abstract of Doctor's degree dissertation. Saint Petersburg, 1997, 70 p.

33. Seredin V.V., Rastegaev A.V., Galkin V.I., Parshina T.Iu., Isaeva G.A. Vliianie davleniia i granulometricheskogo sostava na energeticheskuiu aktivnost glin [Influence of pressure and particle size distribution on the energy activity of clays]. Inzhenernaya geologiya, 2017, no.4, pp.62-71. DOI: 10.25296/1993-5056-2017-4-62-71

34. Seredin V.V., Rastegaev A.V., Medvedeva N.A., Parshina T.Iu. Vliianie davleniia na ploshchad aktivnoi poverkhnosti glinistykh gruntov [Influence of pressure on the active surface area of clay soil particles]. Inzhenernaya geologiya, 2017, no.3, pp.18-27. DOI: $10.25296 / 1993-5056-2017-3-18-27$

35. ISO 13099-2:2012. Colloidal systems Methods for zeta-potential determination. Part 2: Optical methods, IDT, available at: http://files.stroyinf.ru/Data/637/63756.pdf (accessed 6 June 2018).

36. Seredin V.V., Parshina T.Iu. Mass change of bound water in clays under compression. Perm Journal of Petroleum and Mining Engineering, 2017, vol.16, no.1, pp.23-32. DOI: 10.15593/2224-9923/2017.1.3

37. Aizenshtadt A.M., Danilov V.E. Kompleksnyi podkhod k otsenke nanorazmernykh fraktsii polidispersnykh sistem izmelchennykh gornykh porod [Comprehensive approach to the assessment of nanosized fractions of polydisperse systems of crushed rocks]. Nanotekhnologii v stroitelstve, 2016, vol.8, iss.3, pp.97-110. DOI: $10.15828 / 2075-8545-2016-8-3-97-110$

38. Schoonheydt R.A., Johnston C.T. Surface and interface chemistry of clay minerals. Developments in clay science, 2006, vol.1, pp.87-113. DOI: $10.1016 / \mathrm{S} 1572-4352(05) 01003-2$

39. Sanderson R.T. Chemical bonds and bond energy. 2nd ed. New York, Academic Press, 1976, 232 p. 
40. Mortier W.J. Electronegativity equalization and its application. Structure and Bonding, 1987, 66, pp.125-143. DOI: $10.1007 / \mathrm{BFb} 0029839$

41. GOST 12536-2014. Grunty. Metody laboratornogo opredeleniya granulometricheskogo (zernovogo) i mikroagregatnogo sostava [GOST 12536-2014. Soils. Methods of laboratory granulometric (grain-size) and microaggregate distribution], available at: http://docs.cntd.ru/document/1200116022 (accessed 6 June 2018).

\section{Библиографический список}

1. Середин В.В., Красильников П.А., Медведева Н.А. Изменение электрокинетического потенциала глинистых коллоидов в водной и углеводородной средах // Геоэкология, инженерная геология, гидрогеология, геокриология. 2017. - № 1. - C. 66-74.

2. Buckley J.S., Takamura K., Morrow N.R. Influence of electrical surface charges on the wetting properties of crude oils // SPE Reservoir Engineering. - 1989. - Vol. 4, iss. 03. - P. 332-340. DOI: 10.2118/16964-PA

3. Yukselen Y., Kaya A. Zeta potential of kaolinite in the presence of alkali, alkaline earth and hydrolyzable metal ions // Water, Air, and Soil Pollution. 2003. - Vol. 145, № 1-4. - C. 155-168. DOI: $10.1023 / \mathrm{A}: 1023684213383$

4. Середин В.В., Паршина Т.Ю., Исаева Г.А. К вопросу об оценке энергетического потенциала глинистых частиц // Вестник Пермского университета. Геология. 2017. - T. 16, № 4. - C. 370-381. DOI: 10.17072/psu.geol.16.4.370

5. Злочевская Р.И., Королев В.А. Электроповерхностные явления в глинистых породах. - М.: Изд-во Моск. гос. ун-та, 1988. - 177 c.

6. Королев В.А., Нестеров Д.С. Физикохимические закономерности изменения электрических зарядов частиц глинистых грунтов // Инженерная геология. - 2017. - № 4. - С. 50-60. DOI: 10.25296/1993-5056-2017-4-50-60

7. Тарасевич Ю.И., Овчаренко Ф.Д. Адсорбция на глинистых минералах. Киев: Наукова думка, 1975. - 352 с.
8. Van Olphen H., Fripiat J.J. Data handbook for clay minerals and other nonmetallic menirals. - Oxford: Pergamon Press, 1979. $-346 \mathrm{p}$.

9. Соколова Т.А., Трофимов С.Я. Сорбционные свойства почв. Адсорбция. Катионный обмен. - Тула: Гриф и К, 2009. - 172 c.

10. Морис П. Поверхность и межфазные границы в окружающей среде. От наноуровня к глобальному масштабу. - М.: БИНОМ. Лаборатория знаний, 2013. - 543 с.

11. Characterization of the surface charge distribution on kaolinite particles using high resolution atomic force microscopy / N. Kumar, Cunlu Zhao, Aram Klaassen, Dirkvan den Ende, Frieder Mugele, Igor Siretanu // Geochimica et Cosmochimica Acta. - 2016. - T. 175. - P. 100-112. DOI: $10.1016 /$ j.gca.2015.12.003

12. Schoonheydt R.A., Johnston C.T. Surface and interface chemistry of clay minerals // Developments in clay science. - 2006. - T. 1. - P. 87-113. DOI: 10.1016/S1572-4352(05)01003-2

13. Gupta V., Miller J. D. Surface force measurements at the basal planes of ordered kaolinite particles // J. Colloid Interface. Sci. - 2010. - Vol. 344, iss. 2. - P. 362-371. DOI: $10.1016 /$ j.jcis.2010.01.012

14. Воюцкий С.C. Курс коллоидной химии. - Изд. 2-е, перераб. и доп. М.: Химия, 1976. - 512 с.

15. Осипов В.И., Соколов В.Н., Румянцева Н.А. Микроструктура глинистых пород / под ред. акад. Е.М. Сергеева. М.: Недра, 1989. - 211с. 
16. Соколов В.Н. Глинистые породы и их свойства // Науки о земле. - 2000. - Т. 6, вып. 9. - С. 59-65.

17. Стромберг А.Г., Семченко Д.П. Физическая химия. - М.: Высш. шк., 2001. - 527 c.

18. Середин В.В., Андрианов А.В. K вопросу о методике определения прочностных характеристик грунтов // Современные проблемы науки и образования. - 2013. - № 6. - С. 946.

19. Изотерма сорбции ионов стронция монтмориллонит-гидрослюдистыми глинами / Л.Ф. Голдовская-Перистая [и др.] // Сорбционные и хроматографические процессы. - 2011. - Т. 11, № 2. - С. 165-171.

20. Путилина В.С., Галицкая И.В., Юганова Т.И. Сорбционные процессы при загрязнении подземных вод тяжелыми металлами и радиоактивными элементами. Медь // Экология. Серия аналитических обзоров мировой литературы. - 2013. № 100. - C. 3-93.

21. Михайлов Н.Н., Сечина Л.С., Моторова К.А. Роль глинистых минералов в образовании адсорбционно-связанной нефти в породах-коллекторах углеводородного сырья // Георесурсы, геоэнергетика, геополитика. - 2012.- № 1(5). - С. 51.

22. Иванова Е.С. Возможности прогнозирования сорбционной активности природной глины // Известия РГПУ им. А.И. Герцена. Химия. - 2013. - № 157. С. $90-95$.

23. Красильников П.А., Середин В.В., Леонович М.Ф. Исследование распределения углеводородов по разрезу грунтового массива. Фундаментальные исследования. 2015. - № 2-14. - С. 3100-3104.

24. Осипов В.И. Нанопленки адсорбированной воды в глинах, механизм их образования и свойства // Геоэкология, инженерная геология, гидрогеология, геокриология. - 2011. - № 4. - С. 291-305.
25. Королев В.А. Теория электроповерхностных явлений в грунтах и их применение. - М.: Сам полиграфист, 2015. - 468 c.

26. Нестеров Д.С., Королев В.А. О влиянии $\mathrm{pH}$ среды на электрический заряд частиц глинистых грунтов // Геология в развивающемся мире: сб. науч. тр. (материалы IX Междунар. науч.-практ. конф. студ., асп. и молодых ученых): в 2 т. - Пермь: Пермск. гос. нац. исслед. ун-т, 2016. - Т. 1. - С. 451-454.

27. Лин-Гуан-цан, Фридрихсберг Д.А. Исследование электрокинетического потенциала в зависимости от температуры и других факторов // Вестник Ленинградского государственного университета. - 1963. № 16, вып. 3. - С. 88.

28. Авакумов Е.Г., Болдырев В.В. Фундаментальные основы механической активации, механосинтеза и механохимических технологий. - Новосибирск: Изд-во СО РАН, 2009. - 343 с.

29. Исследование изменения элетростатических характеристик глин Таганского месторождения от степени механоактививации [Электронный ресурс] / П.О. Юрьев, И.В. Костин, Е.В. Рассказова, В.В. Цэрна // Молодежь и наука: сб. материалов X Юбилейной всерос. науч.техн. конф. студентов, аспирантов и молодых ученых с международным участием, посвященной 80-летию образования Красноярского края [Электронный ресурс]. Красноярск: Сибирский федеральный ун-т, 2014. - URL: http://conf.sfu-kras.ru/sites/mn2014/ directions.html (дата обращения: 10.06.2018).

30 . Role of surface area, primary particle size, and crystal phase on titanium dioxide nanoparticle dispersion properties / K. Suttiponparnit, J. Jiang, M. Sahu, S. Suvachittanont, T. Charinpanitkul, P. Biswas // Nanoscale Res Lett. - 2011. - Vol. 6, № 1. P. 27. DOI: $10.1007 / \mathrm{s} 11671-010-9772-1$ 
31. Франк-Каменецкий В.А., Котов Н.В., Гойло Э.А. Трансформационные преобразования слоистых силикатов при повышенных $p$-T-параметрах / М-во высш. и сред. спец. образования РСФСР, Ленингр. гос. ун-т. Науч.-исслед. ин-т земн. коры. Л.: Недра, 1983. - 151 с.

32. Гойло Э.А. Кристаллохимия трансформаций слоистых силикатов: автореф. дис. ... д-ра геол.-мин. наук: 04.00.20 / СанктПетербургский гос. ун-т. - СПб., 1997. - 70 с.

33. Влияние давления и гранулометрического состава на энергетическую активность глин / В.В. Середин, А.В. Растегаев, В.И. Галкин, Т.Ю. Паршина, Г.А. Исаева // Инженерная геология. - 2017. - № 4. C. $62-71$. DOI: 10.25296/1993-5056-2017-4-62-71

34. Влияние давления на площадь активной поверхности глинистых грунтов / В.В. Середин, А.В. Растегаев, Н.А. Медведева, Т.Ю. Паршина // Инженерная геология. - 2017. - № 3. - С. 18-27. DOI: $10.25296 / 1993-5056-2017-3-18-27$

35. ISO 13099-2:2012. Colloidal systems Methods for zeta-potential determination. Part 2: Optical methods, IDT [Электронный pecypc]. - URL: http://files.stroyinf.ru/Data/ 637/63756.pdf (дата обращения: 10.06.2018).
36. Середин
B.B.,
Паршина
T.Ю. Изменение масс связанной воды в глинах при сжатии // Вестник Пермского национального исследовательского политехнического университета. Геология. Нефтегазовое и горное дело. - 2017. - Т. 16, № 1. - С. 23-32. DOI: $10.15593 / 2224-9923 / 2017.1 .3$

37. Айзенштадт А.М., Данилов В.Е. Комплексный подход к оценке наноразмерных фракций полидисперсных систем измельченных горных пород // Нанотехнологии в строительстве: научный интернетжурнал. - 2016. - Т. 8, вып. 3. - С. 97-110. DOI: $10.15828 / 2075-8545-2016-8-3-97-110$

38. Schoonheydt R.A., Johnston C.T. Surface and interface chemistry of clay minerals // Developments in clay science. - 2006. - T. 1. - P. 87-113. DOI: $10.1016 / \mathrm{S} 1572-4352(05) 01003-2$

39. Sanderson R.T. Chemical bonds and bond energy. - 2nd ed. - New York: Academic Press, 1976. - 232 p.

40. Mortier W.J. Electronegativity equalization and its application // Structure and bonding. - 1987. - 66. - P. 125-143. DOI: $10.1007 / \mathrm{BFb} 0029839$

41. ГОСТ 12536-2014. Грунты. Методы лабораторного определения гранулометрического (зернового) и микроагрегатного состава [Электронный ресурс]. URL: http://docs.cntd.ru/document/1200116022 (дата обращения: 10.06.2018).

Please cite this article in English as:

Medvedeva N.A., Alvanyan K.A., Malgina Yu.O., Seredin V.V. Zeta potential changing in compressed clays. Perm Journal of Petroleum and Mining Engineering, 2019, vol.19, no.1, pp.4-14. DOI: 10.15593/2224-9923/2019.1.1

Просьба ссылаться на эту статью в русскоязычных источниках следующим образом:

Изменение дзета-потенциала глин, подверженных сжатию / Н.А. Медведева, К.А. Алванян, Ю.О. Мальгина, В.В. Середин // Вестник Пермского национального исследовательского политехнического университета. Геология. Нефтегазовоеигорноедело. - 2019. - Т.19, №1 - С.4-14. DOI: 10.15593/2224-9923/2019.1.1 